\title{
Resolving the Inconsistency Between National and EU Motor Insurance Law. Was Factortame the Solution Nobody Sought?
}

\author{
James Marson ${ }^{1, *}$ (D), Hasan Alissa ${ }^{2, * *}$ and Katy Ferris ${ }^{3, * * *}$ \\ ${ }^{1}$ Sheffield Hallam University, Sheffield, UK, ${ }^{2}$ Sheffield Hallam University, Sheffield, UK and ${ }^{3}$ University of Nottingham, \\ Nottingham, UK
}

(Received 17 February 2020; revised 29 April 2020; accepted 30 April 2020)

\begin{abstract}
In this Article, we argue that the uncertainty of UK national motor vehicle insurance law-when viewed with respect to its European Union (EU) parent, the Motor Vehicle Insurance Directive (MVID) —-was never satisfactorily addressed, primarily when using the remedy available through the non-contractual liability of the State. The EU enforcement mechanisms were equally haphazard in their effectiveness and success in affording rights to third-party victims. Given the link between the MVID and the free movement of persons and goods, on which the harmonization of insurance protection was based, we present the first Article establishing an argument that those offending aspects of UK national law should have been disapplied. The UK has concluded its agreement to withdraw its membership of the EU-and thus no longer to be bound by EU law and the jurisprudence of the Court of Justice. Yet until the transitional period ends, the UK remained aligned to EU law and those defects present in national law should have been remedied. Therefore, the remedy issued from the Factortame line of case authorities may have proven to be the most effective way to grant access to rights which were denied to third-party victims in the UK. Here we present a justification for its application.
\end{abstract}

Keywords: Breach of EU law; Factortame; Francovich v. Italy; HS2; motor vehicles; MVID

\section{A. Introduction}

As is well understood, the European Union (EU), in its present and previous incarnations, was designed to facilitate a common market among its Member States, similar to a domestic market. One of the essential conditions to bring this to fruition was the establishment of the free movement of goods and persons, and key to this aim was the creation of a minimum standard of compulsory motor vehicle insurance. Such a system of compulsory insurance coverage against civil liability, with respect to the use of motor vehicles, would protect the interests of victims of accidents and remove disparities of legal protection among the states. Accordingly, by establishing a system of compulsory motor vehicle insurance between Member States, individuals and other motorists would be free to travel throughout the EU, knowing that minimum standards of coverage would be in place to

\footnotetext{
${ }^{\star}$ Dr. Marson is a Reader in Law at Sheffield Hallam University. He is widely published in the areas of EU law, national motor insurance law and the law relating to the use and regulation of autonomous vehicles.

${ }^{* *}$ Dr. Alissa is a postgraduate researcher from Sheffield Hallam University with an expertise in UK motor vehicle insurance law.

${ }^{* *}$ Dr. Ferris is Associate Professor in Business Law at the University of Nottingham. She writes in the areas of business law, with an expertise in EU law and its compatibility with the law of England and Wales. She is also a member of the University of Nottingham's Rights Lab Beacon of Excellence in the Law and Policy Team.
}

(c) The Author(s) 2021. Published by Cambridge University Press. This is an Open Access article, distributed under the terms of the Creative Commons Attribution licence (http://creativecommons.org/licenses/by/4.0/), which permits unrestricted re-use, distribution, and reproduction in any medium, provided the original work is properly cited. 
compensate the third-party victims of accidents involving motor vehicles. This was achieved first through the Motor Vehicle Insurance Directive (MVID) of $1972^{1}$ and then a subsequent series of MVIDs, ${ }^{2}$ which expanded the protection of third-party victims and required Member States to establish a national compensatory body to provide a remedy to this class of victims in the event that they had no insurer from which to recover damages. ${ }^{3}$ In the UK, this body-established many years prior to the MVID's creation-is the Motor Insurers' Bureau ${ }^{4}$ (MIB); it is a requirement for every insurer operating in the UK to be a member of the MIB. Indeed, a percentage from every motor insurance premium paid in the UK is possessed by the MIB to fund this compensatory scheme.

Due to the nature of the requirement to protect victims in the event of no insurer being available to provide damages, the MIB entered into a series of agreements with the Secretary of State, the UK government. The first agreement was titled the Uninsured Drivers' Agreement, which was to be used where the driver had no insurance policy in place at the time of the accident or where the insurer used a provision within an existing contract to avoid its responsibilities. The second was the Untraced Drivers' Agreement, which was used for events where the vehicle causing the accident could not be traced, for example, with so called "hit and run" incidents. The national legislation in place, the Road Traffic Act 1988 (RTA88) - along with the extra-statutory Uninsured Drivers' Agreement (UDA) and the Untraced Drivers' Agreement (UtDA) — operate to give effect to the MVID and the jurisprudence of the Court of Justice.

Perhaps one of the more controversial aspects of the literature, commentary, and judicial examination of national motor vehicle insurance law has been the discussion surrounding the enforcement of the MVID in the UK. ${ }^{5}$ It has been a consistent source of uncertainty; however, due to the general

\footnotetext{
${ }^{1}$ Council Directive 72/166 of Apr. 24, 1972, On the Approximation of the Laws of Member States Relating to Insurance Against Civil Liability with Respect to the Use of Motor Vehicles, and to the Enforcement of the Obligation to Insure Against Such Liability, 1972 O.J. (L 103) 1 (EEC).

${ }^{2}$ Id.; Council Directive 84/5, 1984 O.J. (LL 8) 17 (EEC); Council Directive 90/232, 1990 O.J. (L 129) 33 (EEC); Council Directive 2000/26, 2000 O.J. (L 181) 65 (EC); Council Directive 2005/14, 2005 O.J. (L 149) 14 (EC); Council Directive 2009/103, 2009 O.J. (L 263) 11 (EC).

${ }^{3}$ Council Directive 84/5, supra note 2 .

${ }^{4}$ Of course, similar organizations exist in each Member State.

${ }^{5}$ As just an example of the critical writing in this area, see Nicholas Bevan's writing for the New Law Journal, which includes: Nicholas Bevan, Motor Insurance Law Change, 166 New L.J., no. 7703, 2016, at 5; Nicholas Bevan, Putting Wrongs to Rights (Pt. 2), 166 New L.J., no. 7701, 2016, at 13; Nicholas Bevan, Putting Wrongs to Rights (Pt. 1), 166 New L.J., no. 7700, 2016, at 17; Nicholas Bevan, Redress Road, 166 New L.J., no. 7700, 2016, at 5; Nicholas Bevan, Still Driving Dangerously, 166 New L.J., no. 7693, 2016, at 18; Nicholas Bevan, A Call for (More) Reform, 165 New L.J., no. 7661, 2015, at 9; Nicholas Bevan, No Through Road, 165 New L.J., no. 7648, 2015, at 7; Nicholas Bevan, Delaney Sets a New Insurance Route, 165 NEw L.J., no. 7644, 2015, at 4; Nicholas Bevan, High Impact, 164 New L.J., no. 7628, 2014, at 5; Nicholas Bevan, Ignore at Your Peril, 164 New L.J., no. 7628, 2014, at 7; Nicholas Bevan, Bad Law, 164 New L.J., no. 7624, 2014, at 7; Nicholas Bevan, UK in Breach over Uninsured Drivers, 164 New L.J., no. 7610, 2014, at 4; Nicholas Bevan, Untraced Drivers' Scheme Is Car Crash, 164 New L.J., no. 7598, 2014, at 4; Nicholas Bevan, On the Right Road (Pt. IV), 163 New L.J., no. 7549, 2013, at 193 (2013); Nicholas Bevan, On the Right Road? (Pt. III), 163 New L.J., no. 7548, 2013, at 160; Nicholas Bevan, On the Right Road? (Pt. II), 163 New L.J., no. 7547, 2013, at 130; Nicholas Bevan, On the Right Road?, 163 NEw L.J., no. 7546, 2013, at 94; Nicholas Bevan, Asleep at the Wheel?, 163 New L.J., no. 7556, 2013, at 10. James Marson and Katy Ferris have published the following: James Marson \& Katy Ferris, Too Little, Too Late? Brexit Day, Transitional Periods and the Implications of MIB v. Lewis, 45 Eur. L. Rev. 415 (2020); James Marson \& Katy Ferris, The Compatibility of English Law with the Motor Vehicle Insurance Directives: The Courts Giveth ... But Will Brexit Taketh Away, 136 L.Q. Rev. 35 (2020); James Marson \& Katy Ferris, For the Want of Certainty: Vnuk, Juliana and Andrade and the Obligation to Insure, 82 MoD. L. REV. 1132, 1132-45 (2019); James Marson \& Katy Ferris, Brexit Means Brexit: What Does It Mean for the Protection of Third Party Victims and the Road Traffic Act?, 39 StatuTe L. Rev. 211, 211-27 (2018); James Marson \& Katy Ferris, Motor Vehicle Insurance Law: Ignoring the Lessons from King Rex, 38 Bus. L. REv. 178, 178-86 (2017); James Marson \& Katy Ferris, Misunderstanding and Misapplication of Motor Insurance Law. Will the Supreme Court Come to the Rescue?, 23 EUR. J. CURRENT LEGAL IssuEs 1, 1-8 (2017); James Marson \& Katy Ferris, The Uninsured Drivers' Agreement 2015 as a Legitimate Source of Authority, 38 STATUTE L. REV. 133, 133-46 (2017); James Marson \& Katy Ferris, Delaney and the Motor Vehicle Insurance Directives: Lessons for the Teaching of EU Law, 51 L. TCHR. 411, 411-17 (2017); James Marson \& Katy Ferris, Which Is the Applicable Law in Recovery of Losses from an Uninsured Driver? Moreno $v$. The Motor Insurers' Bureau [2016] UKSC 52, 22 EuR. J. CURRENT LEGAL Issues 1, 1-3 (2016); James Marson, Katy Ferris \& Alex Nicholson, Irreconcilable Differences? The Road Traffic Act and the European Motor Vehicle Insurance Directives,1 J. Bus. L. 51, 51-70 (2017).
} 
disregard of the law nationally, it has also led to successes where third-party victims of motor vehicle accidents have obtained judgments against the State, under a Francovich ${ }^{6}$ action. Some courts have also been receptive to the indirect effect doctrine, although the distinction between a Marleasing ${ }^{7}$ approach and that required in Pfeiffer ${ }^{8}$ - which expands the duty of purposive interpretation ${ }^{9}$ - seems to have been underutilized nationally. Most recently, in MIB v. Lewis, ${ }^{10}$ the Court of Appeal confirmed that aspects of the MVID have direct effect and the MIB is an emanation of the State. This ruling broadened the opportunity for those directly effective aspects of the MVID to be given effect in national courts. Collectively, each of the above mechanisms - for the enforcement of EU law or the provision of a financial remedy to the victim-have been rather limited in practical terms, frequently because of the opaqueness of the remedies and-as Marson and Ferris ${ }^{11}$ explain-the teaching of EU law principles often fails to instill in future lawyers and judges the muscle memory of comparatively assessing EU laws and their national transposing measures. While not an enforcement mechanism, as it forms part of a body of rules which enables affected individuals to seek redress from the State for damages or loss caused by its breach of EU law, "state liability" is a mechanism which has been available as a source of redress for third-party victims. The doctrine of state liability, established in Francovich, ${ }^{12}$ will be remembered as a means for affected individuals to recover damages-yet, even with some notable successes in the area of motor vehicle insurance, ${ }^{13}$ using it to compel Member States to adhere to their EU legal responsibilities has seen limited success. Indeed, it can also be stated with a degree of certainty that over many years - and, until relatively recently, by the Court of Appeal ${ }^{14}$ and Ward LJ in particular, on frequent occasions - that the courts have been reluctant to find the UK in breach of the MVID. This was notably demonstrated in the failed judicial review of the law started by the charity RoadPeace. ${ }^{15}$ The cases demonstrate the need for fresh thinking around granting third-party victims of motor vehicle accidents access to their EU rights, in light of a recalcitrant $\mathrm{UK}$.

In addressing the instances of the UK breaching its obligations under the MVID, the problems inherent in the available enforcement mechanisms, and the limitations in actions under state liability, an argument is presented for the disapplication of inconsistent national laws in motor vehicle insurance. Thus, Factortame, ${ }^{16}$ as a model to halt the application of laws in breach of the MVID, have ensured compliance with superior EU law in a way that was hitherto impossible to achieve. As far as the authors are aware, at present, there have been no arguments presented on this basis. Also, in light of the dicta in the Supreme Court judgment in $R$ (HS2 Action Alliance Ltd) v. Secretary of State for Transport, ${ }^{17}$ an argument is presented that national courts not only could but were subject to a legal duty to strike down aspects of an Act

\footnotetext{
${ }^{6}$ Joined Cases 6 \& 9/90, Francovich and Bonifaci and Others v. Italy, 1991 E.C.R. I-5357.

${ }^{7}$ Case C-106/89, Marleasing SA v. La Comercial Internacional de Alimentacion SA, 1990 E.C.R. I-4135.

${ }^{8}$ Case C-398/01, Bernhard Pfeiffer et alia v. Deutsches Rotes Kreuz, Kreisverband Walshut eV., 2004 E.C.R. I-8835.

${ }^{9} \mathrm{Id}$. at I-8892 (“ . . . when the national court is seised of a dispute concerning the application of domestic provisions which, as here, have been specifically enacted for the purpose of transposing a directive intended to confer rights on individuals. The national court must ... presume that the Member State, following its exercise of the discretion afforded it under that provision, had the intention of fulfilling entirely the obligations arising from the directive concerned.").

${ }^{10}$ MIB v. Lewis [2019] EWCA (Civ) 909, [2019] 6 WLUK 26 (Eng.).

${ }^{11}$ Marson \& Ferris, Delaney and the Motor Vehicle Insurance Directives, supra note 5.

${ }^{12}$ Francovich and Bonifaci and Others, Joined Cases $6 \& 9 / 90$. The Court ruled that it is a principle of community law, inherent in the system of the EC Treaty, "that the Member States are obliged to make good loss and damage caused to individuals by breaches of Community law for which they can be held responsible." Id. at 37.

${ }^{13}$ Delaney v. Secretary of State for Transportation [2015] EWCA (Civ) 172 (Eng.); EUI v. Bristol Alliance Partnership [2012] EWCA (Civ) 1267 (Eng.).

${ }^{14}$ Bristol Alliance Ltd Partnership v. Williams [2011] EWHC (QB) 1657 (Eng.); Sahin v. Havard [2016] EWCA (Civ) 1202 (Eng.).

${ }^{15}$ RoadPeace v. Secretary of State for Transport and Motor Insurers' Bureau [2017] EWHC (Ch) 2725 (Eng.).

${ }^{16} \mathrm{R}$ v. Secretary of State for Transport, ex p Factortame (No. 2) [1991] 1 AC 603 (appeal taken from Eng.).

${ }^{17} \mathrm{R}$ (HS2 Action Alliance Ltd) v. Secretary of State for Transport [2014] UKSC 3 (Eng.).
} 
of Parliament that failed to comply with EU law. ${ }^{18}$ While it is accepted that Factortame ${ }^{19}$ was based on a treaty article and not an EU directive, the MVIDs have it as their origin to give effect to fundamental principles of the free movement of goods and people. However, by extension, in $H S 2,{ }^{20}$ it was possible to argue-albeit by the judiciary in a hypothetical setting $^{21}$ — that EU Directive 2011/92/EU should prevent the application of inconsistent national law relating to decision-making; in this case, concerning the construction of a new highspeed railway. Thus, in relation to the treaty provisions of free movement of people and goodsFactortame $e^{22}$ - and the adherence of national laws and administrative provisions to comply with an EU directive- $H S 2^{23}$ - the argument presented here may have been accepted and allowed for the full enforcement of EU motor vehicle insurance law in the UK. At least, this would have been possible while the UK was a Member State. ${ }^{24}$

\section{B. The Free Movement Principle and Motor Vehicle Insurance . .}

The free movement of EU citizens within the community can be traced to the establishment of the European Economic Community in $1957,{ }^{25}$ which was later developed under the Treaty of Maastricht in 1992. However, EU citizens' right to move and reside in other EU States with - to some extent-no restriction had not been achieved at this stage but required Directive 2004/38/EC ${ }^{26}$ to be passed, giving effect to this Treaty principle. The ultimate aim of the Treaty, given effect via the enactment of secondary law, was to establish a community where EU citizens could live, travel, and move freely with as few restrictions as possible. It was borne of anti-discrimination and sought to harmonize rules through the community to facilitate the free movement of persons and goods.

Free movement of EU citizens is a fundamental principle of the Treaty, enshrined in Articles 21 and 45 of the Treaty on the Functioning of the European Union (TFEU), as well as Article 3(2) of the Treaty on European Union. Article 45 of the TFEU clearly states that "[f]reedom of movement for workers shall be secured within the [c]ommunity." It is a treaty requirement which has direct effect on national courts of EU Member States, without the need for further legislation for implementation. Therefore, and in order for national States to secure freedom of movement, as required under the Treaty, states need to ensure that people are fully protected when moving from one state to another. In other words, EU individuals shall not face any obstacles that restrict their rights of movement - such as facing different levels of insurance coverage and protections that may undermine their rights when they become victims of incidents involving motor vehicles-simply because they have crossed borders within the community. Any such restriction would be interpreted as a breach of the Treaty and require correction. Furthermore, the EU-in the First $\mathrm{MVID}^{27}$ - aimed from the outset to "liberalise the rules regarding the movement of persons and motor vehicles travelling between Member States." 28 Therefore, EU Member States that have

\footnotetext{
${ }^{18}$ Jay J. Arangones, Regina v. Secretary of State for Transport Ex Parte Factortame Ltd.: The Limits of Parliamentary Sovereignty and the Rule of Community Law, 14 FordHAM INT'L L.J. 778-818 (1990).

${ }^{19}$ Francovich and Bonifaci and Others, Joined Cases 6 \& 9/90.

${ }^{20} R$ (HS2 Action Alliance Ltd), 2014 UKSC 3.

${ }^{21} I d$. at 35.

${ }^{22}$ Francovich and Bonifaci and Others, Joined Cases 6 \& 9/90.

${ }^{23} R$ (HS2 Action Alliance Ltd), 2014 UKSC 3.

${ }^{24}$ With respect to the European Union (Withdrawal Agreement) Act 2020, c. 1 (UK), the UK's transitional period and continued relationship with the EU ceased on December 31, 2020, after which date the commencement of the Act is effective.

${ }^{25}$ Treaty of Rome 1957, Title III and Art. 48.

${ }^{26}$ Council Directive 2004/38 of Apr. 29, 2004, On the Right of Citizens of the Union and Their Family Members to Move and Reside Freely Within the Territory of the Member States Amending Regulation (EEC) No.1612/68 and Repealing Directives 64/221/EEC, 68/360/EEC, 72/194/EEC, 73/148/EEC, 75/34/EEC, 75/35/EEC, 90/364/EEC, 90/365/EEC and 93/ 96/EEC, 2004 O.J. (L 158) 77 (EC).

${ }^{27}$ Council Directive 72/166, supra note 1 .

${ }^{28} I d$. at preamble.
} 
been in breach of these requirements - as the UK was-should correct the wrong and bring their national laws into compliance with the MVID. This ensures the requirements of minimum standards of insurance are met for those traveling throughout the EU, and it further ensures that crossborder travel is harmonized to the extent that people and vehicles do not experience any hinderance when moving from one State to another.

\section{C. .... and its Significance to the Community}

Free movement of people is one of the four founding principles upon which the EU is based. Article 3 of the Treaty of Lisbon provides that " $\mathrm{t}]$ he Union's aim is to promote peace, its values and the well-being of its peoples ... and shall promote social justice and protection." 29 From this, it is derived that free movement is a fundamental principle of the community that cannot be achieved without social justice and protection. The EU's values, found at Article 2 of the Treaty on European Union, which include "equality and the rule of law," cannot be achieved by-for instance-having different treatment for victims of uninsured or untraced drivers in comparison to claims made directly to insurers, just because the driver at fault was uninsured or the vehicle was unidentified..$^{30}$ Furthermore, it breaches citizens' rights to have their rights protected, as it undermines other EU values - for example, the rule of law-when the UK's motor insurance law ${ }^{31}$ breached the MVID.

One of the drawbacks of the First MVID was the disparity in legal protection afforded to thirdparty victims across Member States, which was deemed a substantial barrier to free movement. This was especially apparent in respect of the scope of insurance coverage and the exclusion clauses to the responsibilities of insurers permitted by each state, ${ }^{32}$ undermining the effectiveness of free movement. It entailed passing a second Directive ${ }^{33}$ to remedy these drawbacks. The UK, however, was reluctant to remove these existing obstacles that led to the disparities with respect to the scope and exclusion clauses permitted within its national law. Although the RTA 1930 was the basis on which the First MVID was founded, it was clear that while the EU—since 1983 — was attempting to develop the law to avoid the negative consequences experienced by third-party victims of accidents involving motor vehicles, the UK-and its close relationship with the national motor vehicle insurance industry -was reluctant to adopt the changes required of it. For the EU, the consequence of failing to facilitate free movement would be to undermine the aims of the community-which included facilitation of tolerance across the community, to build trust, and to deepen integration between the different cultures within the EU. Therefore, to preserve the aims of the community and to ensure the protective purposes of the MVID were not undermined by national laws, the law required amendment to facilitate compliance. In the UK, the RTA88 and the MIB Agreements, in many respects, did not comply with the aims of the MVID to provide the precise levels of protection-and thereby facilitating the free movements of people and goods, including vehicles_-in the community.

\footnotetext{
${ }^{29}$ Treaty of Lisbon Amending the Treaty on European Union and the Treaty Establishing the European Community art. 3, Dec. 13, 2007, 2007 O.J. (C 306) 1.

${ }^{30}$ Equality and the rule of law also cannot be achieved if citizens of one community face different legal systems based on where an incident takes place.

${ }^{31}$ Throughout this Article, the terms "UK national law" or "UK law" will be used. This is for simplicity, and to draw attention to the difference between this law-namely, the laws of England and Wales-and those at the EU level.

${ }^{32}$ Compare, for example, the extent of the permissible exclusions of liability, still in existence in Road Traffic Act 1988, c. 52, $\$ 148$ (UK) [hereinafter RTA88], and which have been subject to academic scrutiny and condemnation, with the Court of Justice, in Finanger v. Norway (National Association for Road Traffic Victims, intervening), 3 C.M.L.R. 13 (2006), which stated that:
}

The Motor Vehicle Insurance Directives do not grant national authorities a margin of political or economic discretion with regard to the requirement of insurance... The purpose was to pave the way for a Common Market with free movement, and one of the means was to achieve security for the survivors of road traffic accidents ... The development from the first to the third Directive shows that a strong degree of protection was intended, so that the various exemption rules that existed in certain countries were forbidden.

${ }^{33}$ Council Directive 84/5, supra note 2 . 


\section{But Should the UK's Motor Insurance Law Have Been Disapplied? The Offending Provisions Apt for Disapplication}

In both Delaney v. Secretary of State for Transport ${ }^{34}$ and EUI v. Bristol Alliance Partnership, ${ }^{35}$ not only were national appeal courts confused as to the requirements of UK national law in relation to their EU parent, but the cases were also notable for the claimant successfully obtaining redress from the State in a Francovich ${ }^{36}$ action. However, when one considers the scale of the errors present in the rulings by UK courts, as to the compatibility of national legislation with the MVID, these add weight to the argument for the necessity of a disapplication of the offending laws. This Article continues the discussion by briefly identifying the most egregious breaches of EU law and those areas which required disapplying in the RTA88, UDA 2015, and UtDA 2017. This is not an exhaustive list, but simply a representation of the most obvious and serious breaches of EU law, which affectd the rights of third-party victims. Presented here are examples of the misunderstanding of the two frequent sources of law by the most senior appeal courts in the UK. They are presented to exemplify the misconstruction of legal principles and doctrine, not decisions based on case facts.

\section{The RTA88}

Beginning with the RTA88, the scope of Sections 143, 145, 148, 150, 151(4), and 151(5)—in relation to Sections 151(8), 185, and $192^{37}$ —caused problems for a consistent interpretation of the MVID and remained in breach of EU law until the point of the UK's withdrawal. Section 143 requires that "a person must not use a motor vehicle on a road [or other public place] unless there is in force ... such a policy of insurance ... as complies with the requirements of this part of the Act." 38 This Section was in breach of Articles 1 and 3 of the MVID and the rulings of $V n u k^{39}$ and subsequent case authorities, and this breach continued in relation to Sections 145 and 185 RTA88, with regard to the definition of "motor vehicle." In Vnuk, ${ }^{40}$ the Court of Justice extended the requirement for compulsory motor vehicle insurance to apply to private land. This was in contradiction with the RTA88, which limited compulsory insurance to a "road or other public place." ${ }^{11}$ Despite further rulings confirming this point of law-notably, in Andrade ${ }^{42}$ and Julian $a^{43}$ - and the fact that $V n u k^{44}$ was decided in 2014, the RTA88 was never amended, nor was definitive guidance, to aid legal certainty ${ }^{45}$ issued by the UK government. These cases not only explained the insurance requirement for vehicles used on private land, but also the

\footnotetext{
${ }^{34}$ Delaney, 2015 EWCA (Civ) 172.

${ }^{35}$ EUI, 2012 EWCA (Civ) 1267.

${ }^{36}$ Francovich and Bonifaci and Others, Joined Cases 6 \& 9/90.

${ }^{37}$ These sections provide the definition of road or other public place. This section of the RTA88, supra note 32, breaches Articles 1 and 3 of the Sixth MVID.

${ }^{38}$ Similar requirements are placed on authorized insurers in Section 145. See RTA88, supra note 32, $\$ 145$.

${ }^{39}$ ECJ, Case C-162/13, Damijan Vnuk v. Zavarovalnica Triglav, ECLI:EU:C:2014:2146 (Sept. 4, 2014), http://curia.europa. eu/juris/liste.jsf?num $=$ C-162/13.

${ }^{40} I d$.

${ }^{41} \mathrm{RTA} 88$, supra note $32, \S 145$.

${ }^{42}$ ECJ, Case C-514/16, Isabel Maria Pinheiro Vieira Rodrigues de Andrade, Fausto da Silva Rodrigues de Andrade v. José Manuel Proença Salvador, Crédito Agrícola Seguros-Companhia de Seguros de Ramos Reais SA, Jorge Oliveira Pinto, ECLI: EU:C:2017:908 (Nov. 28, 2017), http://curia.europa.eu/juris/liste.jsf?num=C-514/16.

${ }^{43}$ ECJ, Case C-80/17, Fundo de Garantia Automóvel v. Alina Antónia Destapado Pão Mole Juliana and Cristiana Micaela Caetano Juliana, ECLI:EU:C:2018:661 (Sept. 4, 2018), http://curia.europa.eu/juris/liste.jsf?num=C-80/17.

${ }^{44}$ Vnuk, Case C-162/13.

${ }^{45}$ This is a fundamental aspect of EU law. See Case C-308/06, R (International Association of Independent Tanker Owners (Intertanko)) v. Secretary of State for Transport, 2008 E.C.R. I-4057, para. 69, where the Court said: “The general principle of legal certainty, which is a fundamental principle of Community law, requires, in particular, that rules should be clear and precise, so that individuals may ascertain unequivocally what their rights and obligations are and may take steps accordingly." See also Case C-110/03, Belgium v. Comm'n, 2005 E.C.R. I2801, para. 30; Case C-344/04, International Air Transport Association and European Low Fares Airline Association v. Department for Transport, 2006 E.C.R. I-403, para. 68.
} 
law relating to the concept of the "use of a vehicle." However, in Cameron v. Liverpool Victoria Insurance, ${ }^{46}$ the Supreme Court misinterpreted UK national law and failed to give effect to these rulings. ${ }^{47}$ Similarly, in Pilling $v$. UK Insurance ${ }^{48}$ the Supreme Court also failed to reflect the geographic scope of the MVID and its incompatibility with respect to Section 145 of the RTA88.

Section 148 includes statutory exclusion clauses in motor insurance policies-which, if found, are to be held as void. Section 148(2) allows insurers to escape their responsibilities unless the exclusion falls into one of the "matters" 49 as specified in that section..$^{50}$ It had been questioned in Delaney ${ }^{51}$ whether the list of matters was illustrative or exhaustive. An exclusion of liability for domestic insurers the permissible under the MVID, in Article 13, ${ }^{52}$ and this is the only exclusion clause allowed. The UK's approach - that Section 148(2) is to be interpreted as exhaustive and, therefore, any exclusion of liability outside of these prohibited "matters" is allowed-continued in its legislative form, but was clearly wrong in terms of EU law. The Court of Justice had previously held that the exclusion clause-included under Article 13 of the MVID —-was exhaustive, ${ }^{53}$ but nevertheless, other exclusion clauses should not totally prevent third-party victims from asserting their rights, as responsibility to provide a remedy to third-party victims could be shifted to the national compensatory bodyas required under Article 10 of the same Directive. ${ }^{54}$ Either way, third-party victims were not be left uncompensated. Member States may need to regard the exclusion clauses in Article 13 of the MVID as a minimum requirement, and other exclusions may be considered only with respect to first-, not third-, party victims. The Court of Justice later clarified the issue surrounding the permissibility of other exclusion clauses. No other exclusions may be used against third-party victims. ${ }^{55}$ The Court of Justice, in a string of authorities-Bernaldez, ${ }^{56}$ Correia Ferreira v. Companhia de Seguros Mundial

\footnotetext{
${ }^{46}$ Cameron v. Liverpool Victoria Insurance [2019] UKSC 6.

${ }^{47}$ See Nicholas Bevan, Principle v Process, 169 NEw L.J., no. 7832, 2019, at 14.

${ }^{48} \mathrm{R} \& \mathrm{~S}$ Pilling t/a Phoenix Engineering v. UK Insurance Ltd [2019] UKSC 16.

${ }^{49}$ Such matters include the age or physical/mental condition of persons driving the vehicle; the condition of the vehicle-for example, a car's illegally worn (bald) tires; the number of persons that the vehicle carries; the weight/physical characteristics of the goods which the vehicle carries; the time at which/areas within which a vehicle is used; the horsepower/cylinder capacity or value of the vehicle; the carrying on the vehicle of particular apparatus; or the carrying on the vehicle of any particular means of identification other than that required by law.

${ }^{50}$ It is interesting to note that the exclusion clauses in Section 148(2) RTA88 continue, yet the — similarly unlawful—provision in Section 152 RTA88 has recently been removed in The Motor Vehicles (Compulsory Insurance) (Miscellaneous Amendments) Regulations 2019. See RTA88, supra note 32, $\$ \$ 148(2)$, 152; The Motor Vehicles (Compulsory Insurance) (Miscellaneous Amendments) Regulations 2019, SI 2019/1047, art. 3, para. 6 (Eng.).

${ }^{51}$ Delaney, 2015 EWCA (Civ) 172.

${ }^{52}$ Article 13 of the Consolidated MVID identifies permissible exclusions with respect to third-party victims of road traffic accidents. Under this Article, neither statutory exclusions nor contractual clauses can be used by insurers to avoid liabilities for claims made by third-party victims. However, the Directive does allow a single exclusion where the victim knew that the vehicle he or she is travelling in is stolen and they voluntarily allowed themselves to be a passenger, and the insurer can prove that. This requires actual knowledge on the part of the victim and that the insurer or compensatory body-the MIB in the UK-can prove this.

${ }^{53}$ Case C-129/94, Ruiz Bernáldez, 1996 E.C.R. I-1829.

${ }^{54}$ Member States are, under Article 10 of the Consolidated MVID, required to set up a body with a fund that shall be always available for unsatisfied judgments. Its primary task, in other words, is to ensure that victims of uninsured or untraced drivers are compensated to the minimum required level of compensation that they might secure had the driver causing the accident been insured and the claim brought against their insurer. However, the chosen body has its liability limited to only those vehicles which fall under Article 3, which means that the compensatory body is not responsible for claims caused by derogated vehicles. Nonetheless, this exception is not to be misinterpreted by Member States to avoid liability towards victims of such vehicles, but the States are required to provide another mechanism of compensation such as local authority insurers, securities or another compensation scheme.

${ }^{55}$ Article 3 of the Consolidated MVID is perhaps the most important with regards to the obligation imposed on Members States to ensure third-party victims of road traffic accidents are protected. Under this Article, Member States must ensure that civil liability, in regard of the use of a vehicle on their territory, is covered by a minimum of third-party cover to ensure victims suffering loss or injury in the use of vehicles have their fair compensation met. According to Article 3, insurers are liable and shall compensate third-party victims of road traffic accidents for any personal injuries arising out of the use of a vehicle, regardless of the degree of relation between passengers and the policyholder.

${ }^{56}$ Bernáldez, Case C-129/94.
} 
Confiança SA, ${ }^{57}$ Candolin v. Vahinkovakuutusosakeyhtio Pohjola,${ }^{58}$ Farrell v. Whitty, ${ }^{59}$ and Churchill v. Wilkinson and Tracey Evans ${ }^{60}$-identified the exclusions as illustrative and stated that they could not be viewed as exhaustive, thereby allowing all other exclusions not expressly precluded in this list. In other words, the Court regarded the exclusion clause-allowed under Article 13-as illustrative of what cannot be used against third-party victims. In this respect, unlike exhaustive exclusions, illustrative clauses can be used as guidance by Member States to operate in line with the protective purpose of the MVID by-for instance-using Pfeiffer ${ }^{61}$ to impose similar prohibited exclusions when it comes to third-party victims' rights, and to ensure consistency across the community. Failure to prohibit the use of a wider range of exclusion clauses may lead to a limiting of third-party victims' rights to access compensation, which might lead to different levels of coverage depending on where the accident takes place. Such disparities oppose the uniformity of protection across the community that the MVID aims to achieve. Therefore, third-party victims' rights must be ensured access to fair compensation, either by insurers or the compensatory body. ${ }^{62}$ Returning to UK national law, the law was not certain in this respect as to limits to insurers' rights of applying exclusion clauses, other than the one stated in Article 13 of the MVID. The law did permit a greater range of exclusion clauses, through which an insurer was still capable of undermining third-party victims' rights enshrined by the MVID.

Section 150 of the RTA88 relates to insurance policies issued on the basis of use of the vehicle, for "social and domestic" use only. This provision breached Articles 3 and 12(1) of the MVID, and required the judiciary in the UK to be creative in finding mechanisms and factual constructions to provide protection for third-party victims. ${ }^{63}$

Section 151(4) relates to an exclusion of an insurer's responsibility on the basis of the knowledgewhich, in the UK context, may involve constructive knowledge - of the theft or the unlawful taking of a vehicle, where the third-party passenger is injured. Such an exclusion breached the permissible exclusion identified in Article 13(1) of the MVID. Section 151(5) of the RTA88 places a burden on insurers to fulfill the coverage provided in the insurance policy, regardless of the breach of the policyholder, but -in conjunction with Section 151(8) - allows the insurer to recover any funds paid to the third-party victim from the policyholder. It is possible that the third-party victim might also be the policyholder, as per Churchill Insurance v. Wilkinson and Tracey Evans, ${ }^{64}$ and it was this application of the two aspects of the RTA88 that breached Article 13 of the MVID.

In Delaney v. Pickett ${ }^{65}$ the insurer was successful in obtaining a declaration from the courtsunder Section 152(2) of the RTA88 - due to the insured driver having failed to disclose relevant and material facts which would otherwise have affected the insurer's decision to provide coverage. This was repealed pursuant to Regulation 6 of the Motor Vehicles Compulsory Insurance and Miscellaneous Amendments Regulations 2019. However, the Delaney ${ }^{66}$ decision was issued in 2011, the regulations revoking the offending provision of the RTA88 went into effect on November 1, 2019, and-more importantly-the Court of Justice had ruled that such exclusions were contrary to the MVID in Bernaldez, ${ }^{67}$ from 1996! Indeed, even though a consistent ruling

\footnotetext{
${ }^{57}$ Case C-348/98, Vitor Manuel Mendes Ferreira and Maria Clara Delgado Correia Ferreira v. Companhia de Seguros Mundial Confiança SA, 2000 E.C.R. 1-6711.

${ }^{58}$ Case C-537/03, Katja Candolin, Jari-Antero Viljaniemi and Veli-Matti Paananen v. Vahinkovakuutusosakeyhtiö Pohjola and Jarno Ruokoranta, 2005 E.C.R. I-5745.

${ }^{59}$ Case C-356/05, Elaine Farrell v. Alan Whitty, 2007 E.C.R. I-3067.

${ }^{60}$ Case C-442/10, Churchill Ins. Co. Ltd. v. Benjamin Wilkinson and Tracy Evans v. Equity Claims Ltd., 2011 E.C.R. I00000.

${ }^{61}$ Pfeiffer et al., Case C-398/01.

${ }^{62}$ Subjected to the only permitted exclusion clause in Article 13 of the Consolidated MVID.

${ }^{63}$ Seddon v. Binions [1978] RTR 163 (Eng.); Keeley v. Pashen [2004] EWCA (Civ) 1491, [1491] (Eng.).

${ }^{64}$ Churchill Ins. Co. Ltd., Case C-442/10.

${ }^{65}$ Delaney, 2015 EWCA (Civ) 172.

${ }^{66} I d$.

${ }^{67}$ Bernáldez, Case C-129/94.
} 
was issued by the Court of Justice in Fidelidade-Compania de Seguros SA v. Caisse Suisse de Compensation, ${ }^{68}$ the UK's breach of the MVID and inconsistency with the jurisprudence of the Court of Justice was rejected by Justice Ouseley in the RoadPeace v. Secretary of State for Transport and Motor Insurers' Bureau ${ }^{69}$ judicial review hearing. As recently as 2019, in Colley v. Shuker ${ }^{70}$ the RTA88 Section 152 exclusion was still being applied and used by insurers to escape their responsibilities.

Finally, in Section 192, the definition of "road" continues, despite the implications of $V n u k^{71}$ and the possible misreading, as to the rights and obligations this created for users and, arguably, insurers.

\section{The MIB Agreements: The UDA and the UtDA}

It is true that there existed another route for compensation for third-party victims to pursuewhere insurers succeed in avoiding liability-in the event that the insurer chooses to exercise an exclusion clause. This is where the national compensatory body-the MIB-would be involved, through one of the Agreements - the UDA or UtDA — either dealing with the third-party victim's claim directly or where the insurer would manage the claim through the UDA or UtDA itself. The question, though, is whether the scheme managed by the MIB offered comparable compensation and access to protection, as does a claim directly against the insurer, on the terms found in the policy of insurance. The UK's compensation scheme, which is supposedly designed to protect third-party victims of uninsured drivers and untraced vehicles, could not be deemed as fully implementing the MVID. This would have been a potential aspect for future disputes, as the compensation scheme was neither equivalent nor effective in this respect to the requirements in the MVID. The failure was due to technical knock-out clauses, conflicting provisions, and unfair procedural rules that innocent victims faced when required to pursue their claims through the MIB agreements-which resulted in claims being concluded with lesser or no compensation awarded to victims. When scrutinized, it becomes readily obvious that the MIB's agreements-when compared with the minimum standards required under community law-offered a level of protection to third-party victims that was neither equivalent to that under community law nor under similar claims made directly against insured drivers. The MIB may argue that its agreements complied with the MVID and the differences were not so significant as to hold it, the MIB, to be in breach of the Directive. However, no matter how small the perceived violation of the protection, the result is that the Agreements undermined the effects of the MVID. In Bernaldez, ${ }^{72}$ the Court of Justice stated that insurers can neither rely on contractual terms nor on national law in order to avoid a claim raised by third-party victims. Bernalde $z^{73}$ requires Member States to ensure the effectiveness of the MVID to protect third-party victims of motor accidents. Therefore, the UK was obliged to take into account the EU principles of equivalence and effectiveness ${ }^{74}$ when dealing with claims made against uninsured drivers and with respect to untraced vehicles. Procedural rules, imposed under the UDA 2015 as well as the UtDA 2017, must not deprive innocent third-party victims of road traffic accidents of their rights but ensure the right amount of compensation is awarded. ${ }^{75}$ In other words, to ensure effectiveness and equivalence in this respect, such claims should follow the

\footnotetext{
${ }^{68}$ ECJ, Case C-287/16, Fidelidade Companhia de Seguros SA v. Caisse Suisse De Compensation, ECLI:EU:C:2017:575 (July 20, 2017), http://curia.europa.eu/juris/liste.jsf?num=C-62/14.

${ }^{69}$ RoadPeace, 2017 EWHC (Ch) 2725.

${ }^{70}$ Colley v. Shuker [2019] EWHC (Ch) QB 781 (Eng.).

${ }^{71}$ Vnuk, Case C-162/13.

${ }^{72}$ Bernáldez, Case C-129/94.

${ }^{73} \mathrm{Id}$.

${ }^{74}$ ECJ, Case C-120/97, Upjohn Ltd. v. The Licensing Authority Established by the Medicines Act 1968 and Others, ECLI: EU:C:1999:14, para. 32 (Jan. 21, 1999), http://curia.europa.eu/juris/liste.jsf?num=C-120/97.

${ }^{75}$ Both Agreements govern uninsured driver and untraced vehicle accident claims.
} 
same procedural rules and get the same award as if they had been dealt and awarded by insurers, which was not the case under the existing MIB compensation scheme.

Under Clause 5 of the UDA 2015, the MIB is not liable for any claim "arising out of the use of a vehicle which is not required to be covered by a contract of insurance unless the use is in fact covered by a contract of insurance. ${ }^{.76}$ There are bodies - the National Health Service and the police being the most obvious examples - that would generally be able to meet claims, in the event they do not possess any insurance coverage for accidents involving their vehicles. The MVID, at Article 5, makes no such exception and the result is that a victim of an unauthorized driver-such as, for example, a "joy rider" who steals such a vehicle and causes an accident in the course of this venture-would be unable to recover damages from the MIB, which — as a body — exists to be the insurer of last resort. Clause 6 enables the MIB to avoid liability and/or deduct from payments any amount that a claimant would have been able to secure from another source, subject to certain exclusions. This might include payments from bodies such as the Criminal Injuries Compensation Authority but would also include those from an employer's noninsured refundable advance. This deduction of compensation even extends to situations where the claimant failed to use, or to claim within the required time limits, from a personal insurance scheme. While Article 10 of the MVID does allow for Member States to make deductions from a victim's compensation payments, this was included to prevent the double payment of compensation-where Article 10 specifically refers to "social security bodies required to compensate the victim in respect of the same accident." It does not exist to permit subrogation against victims of motor vehicle accidents. Clause 8 is applicable to situations where the victim allowed themselves to be a passenger in a vehicle to which - either before the start of the claimant's journey or after its start - they knew or had reason to believe that (a) the vehicle had been stolen or unlawfully taken; or (b) the vehicle was being used without there being a contract of insurance complying with the RTA88 in force. MVID Article 10(2) permits the exclusion of liability from the MIB for persons who the Member State-or, in this instance, the MIB-can prove or knew the vehicle in which they were traveling was uninsured. In White $v$. White, ${ }^{77}$ the House of Lords at paragraph 34 of the judgment, extended the concept of knowledge to "turning a blind eye" as to whether insurance was held or not. ${ }^{78}$ However, there is no such inclusion of constructive knowledge in the MVID. It is clear that actual knowledge is required for the application of the MVID, and nothing less than this will offer the victim the same level of protection.

The UtDA 2017 is the most recently altered of the MIB's Agreements—it was effective for accidents occurring on and after March 1, 2017-yet it continued to breach aspects of the MVID. Some of the provisions included are merely archaic, ${ }^{79}$ yet they are fundamentally disadvantageous to claimants to the MIB. Beginning at Section 1(5), the UtDA defines an "authorised person" as:

[A] person acting on the claimant's behalf who is recognised in law as having authority so to act but this does not include a solicitor or other legal representative of the claimant, unless appointed as the claimant's Guardian or Deputy or a person authorised under an Intervention Order pursuant to section 53 of the Adults Incapacity (Scotland) Act 2000. ${ }^{80}$

\footnotetext{
${ }^{76} \mathrm{RTA} 88$, supra note $32, \S 144$.

${ }^{77}$ White v. White [2000] UKHL 54, [2001] 1 AC 596.

${ }^{78} \mathrm{Id}$. at para. 34 .

${ }^{79}$ For example, at Clause 24, the MIB requires notice of documents and claims to be served to it via fax or recorded deliverywhich, incidentally, has been abolished as a form of communication in the UK. MOTOR INSURERS' BUREAU, MIB UNTRACED DRIVERS AGREEMENT 39 (2017), https://www.mib.org.uk/media/355104/amended-2017-untraced-drivers-agreement-englandscotland-and-wales_v10.pdf [hereinafter UTDA]. The MIB does reserve the right to accept communications in another form, but this either has to be the choice of the MIB to accept this form of communication or it has to be conclusively proved that the MIB did in fact receive the notice. In 2017, with the range of electronic communications systems quite readily used by businesses and legal professionals and professional bodies, to insist on the use of such old-fashioned mechanisms remains surprising. It might be surmised that this has been stipulated in the "new" Agreement to make communication of notice more difficult and hence to reduce the number of claims to the MIB.

${ }^{80} I d$. at $1-3$ (emphasis added).
} 
This definition is important with respect to Clause 10(1), which requires that the claimantalbeit with the assistance of an authorized person-comply with the requirements of the clause. Failure to comply enables the MIB to reject the claim. The clause specifically removes the right for a claimant to be assisted, in their action with the MIB, with qualified legal representatives. Given the plethora of irrelevant materials to which the MIB might require the claimant to provide access - and perhaps where a solicitor would have a better awareness of the potential problems and harm this might cause the claimant than a non-legally qualified lay person-the specific removal of lawyers from this aspect of the claim is as surprising as it was worrisome. Completing the claim and early correspondence with the MIB is often the first, crucial stage in a claim, and to prevent a victim from obtaining assistance from a solicitor is quite unusual.

The UtDA includes various procedural aspects which contradict or undermine the effectiveness of the MVID. With regard to damage sustained to property, the UtDA stipulates that an award is conditional on a claimant suffering personal injury from the same accident. The injury must, however, be "significant" in order for the MIB to proceed with the claim for property damage. This means the value of any claims must exceed $£ 400$. Such requirements reflect a general lack of good faith - and while the MIB may argue for the need to take these measures to prevent fraud, they nevertheless should not operate at the expense of innocent victims of untraced drivers. Rather, there should be a balanced assessment, given it is the duty of the MIB to have the right measures to control for such issues, not the victims. Therefore, the MIB should not have been in a position to exploit such incidents to undermine third-party victims' rights of untraced drivers and, thereby, the MVID.

Under Clause 8(1) of the UtDA 2017, the MIB has the right to deny any liability with respect to death, bodily injury, or property damage arising out of the use of a vehicle where a claimant voluntarily let themselves be a passenger in a vehicle and they "knew or ought to have known" that the concerned vehicle a) was stolen or unlawfully taken, or b) uninsured according to the national requirement. ${ }^{81}$ This wording, already identified in the line of judicial reasoning outlined above, continued to use the constructive knowledge definition-which is beyond that allowed in the MVID - and thereby negatively affected the efficacy and protective purpose of the Directive. Indeed, it is in a practical sense difficult to ascertain how a passenger would know-and this being proved - that a vehicle was uninsured. If the MIB could prove that the claimant knew or had reason to believe in any of such matters, then the MIB would be deemed to discharge its duty in respect of knowledge. The knowledge requirements under this Agreement seemed to be sufficiently broad to make it easy for the MIB to shift the burden of proof to the victim, which can be deemed to breach the clear and simple requirement applied under the MVID. ${ }^{82}$

There are certain requirements that any law is expected to respect, and-beyond the formalities of its construction and adherence to constitutional requirements - it should, as a minimum, provide a level of legal certainty-otherwise, its legitimacy may be called into question. One of the fundamental requirements of the UK's constitution - and the rationale advanced that the contravening aspects of the RTA88, UDA, and UtDA should have been disapplied-stems from the European Communities Act 1972, the Treaty of Maastricht and the associated case law, which provides a means for the courts to have adopted this course of action if they had so chosen. It is argued here that the UK's motor insurance laws breached fundamental principles of EU law. The national laws — the RTA88 and the MIB Agreements—may be argued to have breached aspects of the EU's free movement principles when failing to provide the necessary protection for EU citizens; here, it would be third-party victims of motor vehicle accidents. The national law further breached fundamental principles to ensure legal certainty, as it contradicted its EU parent law; although, these principles would not find the remedy in national law being disapplied. Community citizens, under this regulatory regime, would be unable to accurately nor adequately predict their legal position, and therefore their rights, in advance when they decided to travel to, work, or even live in the UK. The UK's

\footnotetext{
${ }^{81}$ RTA88, supra note 32 , at pt. IV.

${ }^{82}$ Phillips v. Rafiq [2007] EWCA (Civ) 74 (Eng.).
} 
withdrawal from the EU-otherwise referred to as "Brexit"-became another source of uncertainty as to whether the UK would leave the Single Market and Customs Union. This does, the UK having chosen to leave without agreement to preserve this relationship, end the UK's duty to fulfill the free movement principles. Furthermore, although not specifically pertinent to the arguments advanced here, national law possibly breaches Article 8 of the European Convention on Human Rights-as it impinges on citizens' right to access to justice. Finally, national law failed to comply with the effectiveness and equivalence principles required under EU law. ${ }^{83}$ The earlier mentioned principles-as they pertain to breaches of EU fundamental doctrine-are discussed in order to explain and offer a legal basis for the advancement of disapplying inconsistent national laws, which breach superior EU laws.

The arguments presented above have been used to not only identify some of the inconsistent judicial practices in the (mis)application of UK national laws, with respect to EU law, but also to highlight some of the procedural and administrative functions which operated to transgress EU law in the UK. Case law is now presented to argue how it was constitutionally possible for national legislation and administrative agreements to be disapplied for breaching EU treaty articles and directive provisions.

\section{E. Disapplying the RTA88, UDA, and UtDA: The Constitutional Argument}

It will likely be questioned in the first instance why, in 2021, an argument is being presented to use a case-established in 1991-to give effect to superior EU law in the courts of a Member State. Surely, the brightest legal minds would have considered-and by implication, rejected — such an argument. We write this because naturally, this is the "elephant in the room," and without addressing it from the outset, it will play on the minds of the readers and possibly distract from the opinions presented. Factortame $e^{84}$ began the constitutional revolution in the UK, whereby an established Act that transgressed EU law should not be enforced. The case law then progressed through Thoburn, ${ }^{85}$ which discussed the different types of Acts and their constitutional hierarchy. Finally, $H S 2^{86}$ enabled the Supreme Court to reflect on the potential for the disapplication of an Act due to incompatibility with a directive. Therefore, given the problems inherent with the statutory - the RTA88 - and extra-statutory provisions - the UDA and UtDA - when considered in light of the MVID and free movement principles, and that in MIB v. Lewis, ${ }^{87}$ the UK appeal courts seemed to accept the transgression of EU law, in some respects-and the status of the MIB and the direct effect of Articles 3 and 10 of the MVID_it seems an apt time to dissect arguments for potential offending national laws having been disapplied as contravening the effectiveness of EU law.

If one begins by examining the constitution upon which the UK is based, one of the first theorists that springs to mind is Dicey-who, as famously instructed to all first-year English law students, concluded that the sovereignty of Parliament is supreme-or limitless - and therefore, it may make and unmake any laws which it chooses. Significantly, "no person or body is recognized by the law ... as having the right to override or set aside the legislation of Parliament." 8 Thus, the legal power vested in the country is qualified by a political reality and this, for Dicey, is the only hierarchy in place. There is - of course-a hierarchy in existence within the sources of law, which will be seen between Acts of Parliament, the common law, conventions, and customs. This is natural. However, the issue is that for Dicey, the Acts themselves are of the same legal

\footnotetext{
${ }^{83}$ Marson \& Ferris, Ignoring the Lessons from King Rex, supra note 5.

${ }^{84}$ Factortame (No. 2), 19911 AC 603.

${ }^{85}$ Thoburn v. Sunderland City Council [2002] EWHC (Ch) 195, [2002] 3 WLR 247 (Eng.).

${ }^{86} R$ (HS2 Action Alliance Ltd), 2014 UKSC 3.

${ }^{87}$ Lewis, 2019 EWCA (Civ) 909.

${ }^{88}$ Albert Venn Dicey \& E.C.S. Wade, Introduction to the Study of the LaW of the Constitution (10th ed. 1965).
} 
power and significance. He did not seek to establish a hierarchy amongst them. Given the flatness of the structure proposed, the legal status of each Act of Parliament is the same.

This view of the legal landscape, in which primary legislation exists, fails to take into account the development of the legal system of the UK, and of what at least became known as constitutional statutes - those which were so fundamental that they could not be, implicitly at least, reversed through implied repeal. Thus, while they became entrenched in the UK's legal system, there remained the possibility of an explicit repeal by a future Parliament if indeed the political will allowed. The Constitutional Reform Act 2005, the Human Rights Act 1998, and-especially for the purposes of this Article - the European Communities Act (ECA) 1972 are each examples of Acts of Parliament which were granted the status of moving beyond "ordinary" Acts and becoming "constitutional."

We can therefore move forward on the basis that, while the UK Parliament and its law-making remains supreme, the content of the laws it produces are subject to a hierarchy in which some Acts have greater powers and significance than others. To begin, it is important to recognize the fundamental influence that Factortame ${ }^{89}$ had on the UK legal system, the rights of individuals within the Member States of the EU, the obligations facing Member States, and the supremacy of EU law over inconsistent national law.

\section{Supremacy of EU Law: A National Court's Duty?}

National courts of EU Member States have a duty to ensure that the principles of community law are protected - a duty they voluntarily undertook. Lord Denning's statement in Macarthys $v$. Smith $^{90}$ reflects how, in the UK, this was achieved through Parliament surrendering its sovereignty to the EU through Section 2 of the ECA 1972. However, the surrender was a voluntary Act of Parliament, and one which it could override if it should so choose. He stated:

If the time should come when our Parliament deliberately passes an Act with the intention of repudiating the Treaty or any provision in it or intentionally of acting inconsistently with it and says so in express terms then I should have thought that it would be the duty of our courts to follow the statute of our Parliament. ${ }^{91}$

Consequently, unless explicitly provided for in the text or preamble of an Act, Parliament's intention when it legislated was to follow and - if applicable — to give effect to EU law. As demonstrated in Unibet (London) Ltd. v. Justitiekanslern, ${ }^{92}$ for instance, many authorities were provided where EU Member States are obliged to give effect to the community law and to ensure that the rights conferred on EU individuals by these laws are protected. Therefore, and to do so, national courts must work in conformity with EU law and take into account the purpose of EU legislation to ensure compatibility and consistency in approach. Further, in $R v$. Transport Secretary Ex $p$ Factortame Ltd (No.2), ${ }^{93}$ Lord Bridge stated that the ECA 1972 is clear that EU Member States shall give priority to community law where there are conflicts with national laws. National courts cannot compromise on individuals' rights or permit any breaches to EU principles. Moreover, Lord Harwich held that community rights conferred on EU citizens were to be protected by national courts and could be, in these circumstances, directly enforced. In this respect, the courts in Member States are not allowed to undermine community law by-for instance-preventing its effectiveness. To give effect to this principle, national courts were able

\footnotetext{
${ }^{89}$ Factortame (No. 2), 19911 AC 603.

${ }^{90}$ Macarthys Ltd. v. Smith [1979] 3 All ER 325 (Eng.).

${ }^{91} I d$. at 329.

${ }^{92}$ ECJ, Case C-432/05, Unibet (London) Ltd v. Justitiekanslern, ECLI:EU:C:2007:163 (Mar. 13, 2007), http://curia.europa. eu/juris/liste.jsf?num $=$ C-432/05.

${ }^{93}$ Factortame (No. 2), $19911 \mathrm{AC}$ at 659.
} 
to set aside any rules that undermine the effectiveness of EU law and were to enforce community law. ${ }^{94}$ However, in regard of an award for damages to victims of a State's failure to implement EU law as required by Francovich ${ }^{95}$ Evans v. Secretary of State for the Environment, Transport and the Regions ${ }^{96}$ clarified that such an award is only granted upon the satisfaction of three conditions: (i) the law in breach shall grant to individuals a direct right with regard to the disputed area; (ii) the breach shall be sufficiently serious; and (iii) the loss to the victim must be as a direct consequence of the breach by the State-the loss was due to the failure in correctly implementing EU law.

\section{The Tripartite Test-The Limiting Factor}

It was in Delaney v. Pickett ${ }^{97}$ where the Court of Appeal referred to the judgment of Justice Jay, at first instance, where he held that the MVID satisfied the tests and allowed the claimant to recover damages from the UK. Typically, it is the second test which limits the success of recovering compensation. It is a trite comment and the arguments are well rehearsed elsewhere, but essentially, Member States were to be protected where they had breached EU law and this had caused the claimant quantifiable loss, but the breach had been the result of an innocent mistake or administrative error on the part of the State. It would be unfair to hold a State liable for each loss sustained by claimants in such circumstances, particularly when the Court of Justice was placed as a court of reference to determine any error and offer more clear and purposive instruction as to the point of law or the interpretation that should have been used by the court. The result was the "sufficiently serious" element of the test, which negated the efficacy of the remedy of state liability. Of course, in relation to the MVID, the breaches of EU laws and principles in national law have often been so flagrant and clear that they pass the threshold for establishing the State's liability. Nevertheless, and as mentioned earlier, even though Francovich ${ }^{98}$ offers some methods of remedying the financial losses suffered by the claimant, it does not correct the wrong - the breach - by bringing the national law in breach into line with its EU parent. Consequently, the victims who choose not to seek this remedial route would suffer the negative consequences of being left uncompensated, which opposes the protective purpose of the MVID — to facilitate the free movement of people and goods throughout the community. Article 4 of the MVID prohibits Member States from carrying out insurance border checks on vehicles based in other Member States, as such checks could amount to a hinderance of the principle of free movement.

\section{Key Cases and the Development of the UK Constitution}

It is unlikely to be controversial to comment that one of the most remarkable movements in the history of the EU was the Court of Justice's ruling in Von Colson and Kamann v. Land NordrheinWestfalen..$^{99}$ Here, the Court empowered national courts to interpret its laws rationally, in accordance with the wording and aims of EU law. The EU had created-it will be remembered-a "new legal order" in which EU law was superior to national law, which was a principle establishing the indirect effect of EU law. ${ }^{100}$ In Marleasing, ${ }^{101}$ the Court of Justice instructed the courts of Member States that they should, as far as is possible, interpret national law to give effect to the content and spirit of the EU parent law. This philosophy was furthered in the Court's 2004 ruling in Bernhard

\footnotetext{
${ }^{94}$ Treaty of Rome art. 5, Mar. 25, 1957, 298 U.N.T.S. 3.

${ }^{95}$ Francovich and Bonifaci and Others, Joined Cases 6 \& 9/90.

${ }^{96}$ Evans v. Secretary of State for the Environment, Transport and the Regions [2004] EWHC (QB), [2004] RTR 32 (Eng.).

${ }^{97}$ Delaney, 2015 EWCA (Civ) 172.

${ }^{98}$ Francovich and Bonifaci and Others, Joined Cases 6 \& 9/90.

${ }^{99}$ Case 14/83, Von Colson \& Kamann v. Land Nordrhein-Westfalen, 1984 E.C.R. I1891.

${ }^{100}$ See Marleasing SA, Case C-106/89.

${ }^{101} I d$.
} 
Pfeiffer et alia $v$. Deutsches Rotes Kreuz, Kreisverband Walshut eV. ${ }^{102}$ Here, those same national courts - as emphasized by the Court of Justice-should play a greater role in protecting individuals' rights, conferred on them by EU laws, when interpreting national law. Concurrently, national courts were charged with not preventing any provision from undermining the purpose of the MVID. ${ }^{103}$ These cases established that, even prior to the UK joining the EU, EU law was accepted-and had to be accepted by new entrant states-as superior to national law. Without such a ceding of sovereignty, the legal system of the EU and the development from an economic community to a union of states would not be achievable. The Member States, in ensuring EU law was superior to national law, would have their rights to establish new laws in contradiction of EU law curtailed. When interpreting and applying existing laws, which were either created to transpose the effects of secondary sources of EU law-directives-or could be interpreted as being affected by an EU law, the courts in those jurisdictions had a positive duty to give effect to the EU law-direct parent law or not. Even with the duty of purposive statutory interpretation applying to national and EU law, numerous examples have been presented in this Article where national courts have adopted a holistic approach and concluded that - on the whole -national law conforms with the requirements of the MVID. See Roadpeace. Therefore, the value of the Marleasing ${ }^{104}$ and Pfeiffer ${ }^{105}$ line of reasoning -in establishing a consistent interpretation of national law, in light of the MVID — has been haphazard and has not produced any semblance of legal certainty for any of the parties to motor vehicle insurance law. While much of this Article uses cases where the national court has failed to interpret national law consistently with the MVID, positive examples do exist-for example, Churchill v. Wilkinson. ${ }^{106}$

Most recently, in MIB v. Lewis, ${ }^{107}$ the Court of Appeal held the MIB to be an emanation of the State, reversing years of inconsistent national rulings-indeed, by the same judge who had previously ruled that the MIB did not possess this status. It also confirmed the direct effect of both Articles 3 and 10 of the MVID. This would provide a greater range of rights to be exercised in UK national courts-basing arguments directly on Articles 3 and 10 of the MVID and thus superseding the offending aspects of the RTA88, UDA, and UtDA. However, and to place the significance of this judgment in context, the direct effect of the Articles will not-in the absence of knowledgeable lawyers and a receptive judiciary_result in significant change in the application of the law. For legal certainty, the case law may be amended through subsequent judgments but the provisions within the legislation and extra-statutory Agreements are not changed, which compromises legal certainty. However, the status of the MIB — as a body of the State-would perhaps ease the argument that the Agreements it produces with the Secretary of State are susceptible to disapplication, in a similar way to the Acts of Parliament and functioning administrative agreements.

Ultimately, the UK judiciary too often seemed unwilling to consider EU law when establishing a ruling - or when cases heard at the same time, but in different courts in the UK, held opposite views on how to give effect to $\mathrm{EU}_{\text {law }}{ }^{108}$ _leading to an inconsistent interpretation between the two laws. This, in turn, undermined the protective purpose of the MVID.

\footnotetext{
${ }^{102}$ Pfeiffer et al., Case C-398/01.

${ }^{103}$ See, e.g., Bernáldez, Case C-129/94; Farrell, Case C-356/05.

${ }^{104}$ See Marleasing SA, Case C-106/89.

${ }^{105}$ Pfeiffer et al., Case C-398/01.

${ }^{106}$ Churchill v. Wilkinson [2012] EWCA (Civ) 1166, [2012] All ER (D) 47 (Eng.).

${ }^{107}$ Lewis, 2019 EWCA (Civ) 909.

${ }^{108}$ For an MVID compliant interpretation of the RTA88 and UDA, see Allen v. Mohammed and Allianz Insurance [2016] LTL 25/10/2016 (Eng.). And for an inconsistent interpretation of EU law, based on a "holistic" comparison between the EU laws and the suite of national legislative and administrative provisions, see Sahin v. Havard and Riverstone Insurance (UK) Ltd [2016] EWCA (Civ) 1202 (Eng.). Again, here, the lower court gives effect to the MVID and the appeals court views national law as compliant in its current state.
} 


\section{Factortame, Thoburn, and HS2: A Triumvirate of Constitutional Development}

If an argument is to be made that it was necessary and possible-both legally and politically-to disapply the RTA88, UDA, and UtDA in areas where they breach the MVID, it is right to begin with the case which established this change in the UK's constitution. The UK does not possess a constitutional court, its constitution is uncodified and subject to change, and the separation of powers does not grant a right for any court to strike down legislation. These facts are an established feature in UK constitutional law.

\section{Factortame}

The problem in this case began when Spanish-owned vessels started overfishing in UK territorial waters. Under the Treaty of Rome, the free movement principles enabled EU citizens to enter another Member State with the intention of working. The Spanish fishermen were such individuals. They had started by fishing and selling their catches in their home country, but they soon discovered that other fish-which did not sell particularly well in Spain-did have a market in the UK. This led to the influx of new entrants to the fishing market in the UK, and local fishermen were concerned about their livelihoods. It has to be remembered that these fishermen were fishing around the ports in the south of the country, and these were traditionally Conservative-voting constituencies. With a threat that these areas would change their political votes, especially having seen what the Conservative governments had done to the coal and steel industries in the north of the country, the government was faced with a problem. Should it follow EU law and continue to allow the Spanish fishermen and citizens from other Member States to have access to the waters and fish, or should it establish legislation to curtail the influx? The result was the government ceding to the pressure by the national fishing lobby and enacting the Merchant Shipping Act 1988 (MSA88). The MSA88 imposed conditions on those who wished to fish in British waters. Either the fishermen had to be domiciled in the UK or the vessel itself had to be registered in the UK. This would effectively limit access to fishermen from other Member States, who would be unlikely to wish to satisfy either criteria. Of course, the Act contradicts one of the most important principles of the community-free movement. The argument presented in court ${ }^{109}$ was for the EU Treaty offending MSA88 to be disapplied, so as not to breach this fundamental Treaty right. It was appealed to the House of Lords, who believed that applying the requested intervention might subvert the concept of parliamentary sovereignty, as the MSA88 was approved by Parliament ${ }^{110}$ and the judiciary had no constitutional power to refuse to give effect to an Act of Parliament. Consequently, the Lords referred the case to the Court of Justice-which declared that the MSA88 breached EU law, and as the law of EU is supreme, ${ }^{111}$ interim relief was necessaryand the UK chose to disapply the Act accordingly. ${ }^{112}$

Prior to Factortame, ${ }^{113}$ it was understood that national courts had no power to strike down any legislation passed by the Parliament. The role of the courts is to interpret the law, not to make it. ${ }^{114}$ However, the Court of Justice empowers national courts of EU Member States to read and

\footnotetext{
${ }^{109}$ The case was brought by Spanish company Factortame Ltd. and almost 100 other Spanish fishing companies. They claimed compensation for losses while their ships were unavailable for use over a three-year period, from 1988-1991.

${ }^{110}$ The case sparked a debate on whether the constitutional principle of parliamentary sovereignty was being eroded. However, Lord Woolf, Master of the Rolls—sitting with Lord Justice Schiemann and Lord Justice Robert Walker-ruled that ninety-seven owners and managers of vessels were entitled "in principle" to recover damages.

${ }^{111}$ European Communities Act 1972, c. 68, $\$ \$ 2(1), 2(4)$ (UK) [hereinafter ECA].

${ }^{112}$ Three years later, the Court of Justice overturned the UK's legislation. It also ruled that Member States must pay compensation where a breach of European law was deemed "sufficiently serious." See Cases C-46/93 and C-48/93, Brasserie du Pêcheur SA v Bundesrepublik Deutschland; The Queen v Secretary of State for Transport, ex parte Factortame Ltd and others ('Factortame III') EU:C:1996:79, [1996] E.C.R. I-1029, 5 March 1996.

${ }^{113}$ Factortame (No. 2), 19911 AC 603.

${ }^{114}$ The House of Lords refused to rule on this matter, as it may subvert the concept of parliamentary sovereignty, and referred the case to the Court of Justice.
} 
interpret legislation in a way that gives effect to EU law-through consistent interpretation and methods of reasoning to ensure consistency in the community. But, such empowerment is still limited in the UK and any interpretation must not go against the spirit of the UK legislation, in spite of the fact that Factortame $e^{115}$ is a British case. Nonetheless, this may raise another question of the constitutional position of the courts, as their interpretation of EU law may lead them to either overrule Parliament or to disregard EU law in a case of irreconcilable differences between the two. The ruling in Factortame ${ }^{116}$ provoked outrage because of how it undermined Parliamentary sovereignty. ${ }^{117}$ The government, however, was not ignorant ${ }^{118}$ of the fact-as is also the case in matters related to third-party victims of road traffic accidents - that any legislation that undermines any principle of EU law, such as free movement, is a clear breach of EU lawwhich the UK is legally bound by-and negative consequences may follow as a result of passing the MSA88. Yet, the government's challenge to the Court of Appeal was dismissed, and the House of Lords stated that the disapplication was due to a breach of one of the most important principles of community law, and therefore justified in the circumstances.

The MSA88 holds a unique place in the history of the UK constitution, being the only Act which the courts would not apply. It was for Parliament to determine whether the MSA88, as it was written, should be applied. If it was the intention of Parliament to breach a fundamental principle of EU law, it was able to do so. Adopting Denning's position in Macarthys v. Smith, ${ }^{119}$ the national courts would follow Parliament's instruction to adhere to the national law, even where it was in conflict with a superior EU law. The EU law in question was only superiorin the instance of the MSA88-because Parliament had instructed the judiciary of this point in Section 2 of the ECA 1972, ${ }^{120}$ and Parliament was equally empowered to revoke this instruction in relation to the MSA88 or generally to all laws if it chose. ${ }^{121}$ The Lords had decided that such a fundamental breach could not have been the intention of Parliament, and they held accordingly.

\section{Thoburn}

It will be noted that one of the most significant features of the Factortame (No. 2) ${ }^{122}$ case is that, despite the importance that it has for the UK and its relationship with the EU, there is a general lack of detail and discussion on the constitutional theory and practicalities of - on the one hand-the principle of parliamentary sovereignty and-on the other hand-the supremacy of EU law. It was not until the 2002 Thoburn $^{123}$ case that the reasoning of the court shed light on this particular issue. The case was widely known and considered at the turn of the new millennium. Council Directive 80/ 181/EEC had established the requirement for goods widely sold-exceptions were incorporated in the Directive but do not require consideration for the purposes of this Article-to have the legal units of weight represented according to metric measurements. The Directive further allowed for supplementary indications of measurements-essentially allowing Member States, such as the UK, to continue using the Imperial measurement system until the end of 2009. The incorporation of the Directive into national, amending legislation — the Weights and Measures Act 1985led to four appellants, known widely at the time as the "metric martyrs," who had been convicted of

\footnotetext{
${ }^{115}$ Factortame (No. 2), 19911 AC 603.

${ }^{116} I d$.

${ }^{117}$ Adam Wagner, Does Parliamentary Sovereignty Still Reign Supreme?, GuARDIAN (Jan. 27, 2011), https://www. theguardian.com/law/2011/jan/27/supreme-court-parliamentary-sovereignty.

${ }^{118}$ The law lords held that the government had deliberately decided to run the risk of introducing the legislation, knowing that it could be unlawful. Justice required that the wrong should be made good.

${ }^{119}$ Macarthys Ltd., 19793 All ER at 329.

${ }^{120}$ The ECA provides that EU law is to prevail over inconsistent Acts of Parliament "passed or to be passed." ECA $\$ 2(4)$.

${ }^{121}$ At least, this was the thinking at the time, until the Miller and Cherry cases clarified the mechanism needed to repeal the ECA.

${ }^{122}$ Factortame (No. 2), 19911 AC 603.

${ }^{123}$ Thoburn, 2002 EWHC (Ch) 195.
} 
offenses relating to the use of Imperial measurements. It was the use of the "Henry VIII" powers by the Secretary of State - to amend the $1985 \mathrm{Act}$ - which was the focus of the appeal. The main argument was that the amendment to the 1985 Act had impliedly repealed Section 2(2) of the ECA 1972, on the basis that the ECA 1972 established a general provision regarding amending legislation and the more recent 1985 Act was a specific provision. Lord Justice Laws was not convinced with the legal basis of the argument but, to provide certainty regarding the issue - in case he was incorrect in his analysis-Lord Justice Laws continued by examining the nature of the ECA 1972, and whether and how implied repeal through inconsistent provisions in later statutes might affect its standing. Previous authorities were discussed and the fundamental principles, which are very well known and need not be replicated here, were considered. The result was that Parliament and the legislature could not bind future parliaments- the doctrine of implied repeal continued as a fundamental matter of British national constitutional law.

However, Lord Justice Laws went further. He remarked that implied repeal is actually context sensitive and, as legislation could be "ordinary" or of a "constitutional" nature, implied repeal operates-as it is known to do so-in relation to ordinary legislation. With regard to constitutional statutes, ${ }^{124}$ these had to be treated differently. Therefore, Lord Justice Laws considered that:

Ordinary statutes may be impliedly repealed. Constitutional statutes may not. For the repeal of a constitutional Act or the abrogation of a fundamental right to be effected by statute, the court would apply this test: is it shown that the legislature's actual - not imputed, constructive or presumed - intention was to effect the repeal or abrogation? I think the test could only be met by express words in the later statute, or by words so specific that the inference of an actual determination to effect the result contended for was irresistible. ${ }^{125}$

The ECA 1972 is a constitutional statute, but the overriding nature of the UK's Parliament-it being a sovereign - must surely work to resist any limitations on its own power. Perhaps Wade is correct, and sovereignty is now a "freely adjustable commodity." ${ }^{26}$ The answer seems to be found in the text of the ECA 1972 itself and the powers it provides to the judiciary, in matters of resolving conflicts between national and EU laws. In terms of implied repeal, the ECA 1972 is impenetrable to implicit repeal or contradiction, albeit still subject to the express repeal of a sovereign Parliament. Thus, Thoburn ${ }^{127}$ establishes a continuation of the theory of parliamentary sovereignty. Therefore, in relation to any difference in approach by the judiciary-in its interpretation of the RTA88, UDA, and UtDA - the ECA 1972 is immune from any sense of implied repeal. It takes precedence over the statute and extra-statutory provisions, and the clear instruction in Section 2 of the ECA 1972-that "[a]ll rights, powers, liabilities, obligations and restrictions ... created or arising by or under the Treaties, and all such remedies and procedures ... provided for by or under the Treaties, are without further enactment to be given legal effect or used in the United Kingdom"-instructs the judiciary as to this supremacy.

\section{R (HS2 Action Alliance Ltd) v. Secretary of State for Transport}

The case involved the application of Directive 2011/92/EU and its imposition of decision-making in relation to, for the purposes of the case, the construction of the proposed highspeed rail network known as HS2. The Supreme Court was tasked with deciding if the UK's approach to the process adopted in $H S 2^{128}$ was in compliance with the requirements laid down in the Directive. The

\footnotetext{
${ }^{124}$ The Magna Carta Libertatum 1215 (Eng.); the Bill of Rights 1688, 1 W. \& M. 2 c. 2 (Eng.); the ECA; the Human Rights Act 1998, c. 42 (UK); the Scotland Act 1998, c. 46 (UK); and so on would likely be considered "constitutional" in nature.

${ }^{125}$ Thoburn, 2002 EWHC (Ch) 195, 20023 WLR at para. 63.

${ }^{126}$ Henry W.R. Wade, Sovereignty-Revolution or Evolution?, 112 L.Q. REV. 568, 573 (1996).

${ }^{127}$ Thoburn, 2002 EWHC (Ch) 195.

${ }^{128} R$ (HS2 Action Alliance Ltd), 2014 UKSC 3.
} 
mechanism used to give effect to the transposition of the Directive was a "hybrid bill"-one which begins life as a public bill, but which adds an additional select committee stage following the second reading in each House. ${ }^{129}$ It is at this stage where objections from those directly affected by the bill can be raised and where issues may be heard. It was this mechanism which was scrutinized by the Court, with the issue of the potential concern that this form of scrutiny may encroach into the relationship between Parliament and the courts, per Lord Reed. It transpires that Lord Reed did not consider there to be any constitutional problem with the manner in which the Directive had to be implemented in national law, but it was interesting that the obiter provided where he hypothesized what would have been the result had there been such a problem from the Directive.

Lord Reed surmised that had the Directive called upon the UK to adopt a system of close judicial scrutiny of a bill on its passage through Parliament, aligning EU law with national law would not have been as straightforward as the application of the doctrine of the supremacy of EU law. The doctrine derives from the ECA 1972 and matters regarding conflicts between constitutional principles must be resolved by national courts, according to principles of national constitutional law. Further, Factortame (No. 2) ${ }^{130}$ was of no use in these circumstances, as the matter there was the breach of EU law following the enactment of an Act of Parliament, not the process of the making of national law and its compatibility with superior EU law. The conclusion to be drawn is that in HS2, ${ }^{131}$ Lord Reed is explaining how the application of EU law in the creation and interpretation of national law is not merely subject to the existence of the ECA 1972, but rather includes many other dimensions to national constitutional law which may have an affect.

\section{Disapplication Beyond the MSA88?}

The three cases mentioned come together to form the basis for a legal argument that the directly effective elements of the MVID — where they are breached by the RTA88, UDA, and UtDA — may lead to the disapplication of those offending aspects of national law. In Factortame (No. 2), ${ }^{132}$ the decision of the Lords to direct the disapplication of sections of the MSA88 was due to the ECA 1972 providing for EU law to take precedence over national law and the MSA88 Act not derogating from the constitutional powers of the ECA 1972. Had Parliament intended the MSA88 to take effect over the provisions contained in the ECA 1972, it could and would have explicitly done so. Thoburn ${ }^{133}$ continues this approach of parliamentary sovereignty and pragmatic primacy of EU law, by demonstrating Parliament's continued power to derogate from EU law, albeit when it expressly identifies its intention to do so. The problem with this approach, while theoretically sound, is that it begins to unravel when considered in reality. As has been demonstrated throughout the Brexit negotiations and internal wrangling in Parliament, it is not simply the case that the government can choose to remove or suspend parts of the ECA 1972 when it seems politically expedient to do so. This would require an Act of Parliament specifying the clear intention for the particular Act in question to be read as intending to circumvent or directly transgress aspects of the ECA 1972. In its absence, there would also be the political fallout from the EU itself, a breach by the UK of its EU obligations, and a denial of the legitimacy of the action by the Court of Justice. As a consequence, while the position in Thoburn ${ }^{134}$ is academically correctin as far as the UK's ability to derogate from its EU obligations and the primacy of EU law is concerned-practically, however, this is little more than a theoretical construct. There also

\footnotetext{
${ }^{129}$ The Speaker in the House defined a hybrid bill as "a public bill which affects a particular private interest in a manner different from the private interests of other persons or bodies of the same category or class." 669 Parl Deb HC (5th ser.) (1962) col. 45 (UK).

${ }^{130}$ Factortame (No. 2), 19911 AC 603.

${ }^{131} R$ (HS2 Action Alliance Ltd), 2014 UKSC 3.

${ }^{132}$ Factortame (No. 2), 19911 AC 603.

${ }^{133}$ Thoburn, 2002 EWHC (Ch) 195.

${ }^{134} I d$.
} 
remains the very real issue of what type of statute would be necessary to override an existing constitutional statute. This calls into question the issues of hierarchy between such laws and, as provided by Lord Justice Laws, a "specific" form of derogation will be required to achieve an "inference of an actual determination to effect the result contended for was irresistible." 135 This will allow for protection against accidental or incidental derogation, but the interpretation of such will fall to each court to determine. What it does not achieve, though, is reconciling the stark difference between traditional legal theory-Thoburn ${ }^{136}$ reinforces the principle of sovereignty of Parliament and its legitimacy that specific legislation can derogate from otherwise entrenched legislation with the status of being "constitutional" in nature-and political reality. The UK voluntarily acceded to be a Member State of the EU, and to accept with this status the primacy of EU over national law in areas where the EU has competence. It is naïve to infer that Parliament may simply express a willingness to override the EU Treaty and for this position to be accepted by the courts. Although, of course, the Thoburn ${ }^{137}$ judgment appeared to suggest this. However, towards the conclusion of his judgment, Lord Justice Laws offered an interesting insight into a modernization of that constitutional view:

[Parliament] Being sovereign, it cannot abandon its sovereignty ... This is, of course, the traditional doctrine of sovereignty. If it is to be modified, it certainly cannot be done by the incorporation of external texts. The conditions of Parliament's legislative supremacy in the United Kingdom necessarily remain in the UK's hands. But the traditional doctrine has in my judgment been modified. It has been done by the common law, wholly consistently with constitutional principle. ${ }^{138}$

Here, Lord Justice Laws notes that Parliament's legislative authority derives from its common law roots, and it is in the common law where it may be subject to modification. Therefore, as the common law is the source of Parliamentary sovereignty, it may also be used to alter what is known of as sovereignty. This, for Lord Justice Laws, has been ably demonstrated in the creation of exceptions to the doctrine of implied repeal. ${ }^{139}$ It also permits, if such an argument is advanced to a natural conclusion, for the common law to decide-if it wishes - to create constitutional legislation which, through interpretation, is so important that it would be inappropriate for a Parliament to nullify -implicitly or explicitly. The common law will thereby be the arbiter of what might be recognized as constitutional legislation or, conversely, of a lesser hierarchical standing. Accordingly, the Thoburn ${ }^{140}$ ruling is at times confused as to which authority-parliamentary or common law-determines the entrenchment of legislation. Ultimately, Thoburn ${ }^{141}$ reflects a new view of the constitution. Here, Parliament's sovereignty is not so much a "political fact" in the Wade sense of its understanding ${ }^{142}$-rather, it is a legal phenomenon subject to the common law. It need not invoke unconstitutional behavior on the part of the courts to produce a Factortame (No. 2) $)^{143}$ and Thoburn ${ }^{144}$ result. These cases are the very result of the courts "discharging their constitutional role." ${ }^{\text {"45 }}$

\footnotetext{
${ }^{135} I d$. at para. 63.

${ }^{136} I d$.

${ }^{137} I d$.

${ }^{138} I d$. at para. 59.

${ }^{139}$ Thoburn, 2002 EWHC (Ch) 195, 20023 WLR at para. 60.

${ }^{140} I d$.

${ }^{141} I d$.

${ }^{142}$ Henry William Rawson Wade, The Basis of Legal Sovereignty, 13 CAMBRIDGE L.J. 172 (1955).

${ }^{143}$ Factortame (No. 2), 19911 AC 603.

${ }^{144}$ Thoburn, 2002 EWHC (Ch) 195.

${ }^{145}$ Mark Elliott, Embracing “Constitutional” Legislation: Towards Fundamental Law?, 54 N. IR. L.Q. 1, 18 (2003).
} 
This brings us to the most recent case, HS2. ${ }^{146}$ If we accept the proposition of Lord Reed, in his dictum, the stark and binary distinction between ordinary legislation and constitutional legislation is too simplistic in approach. Thoburn ${ }^{147}$ established the distinction and hierarchy between ordinary and constitutional legislation, but it left open the debate of whether all constitutional legislation is of the same status. Could there be nuances and hierarchies present in constitutional laws? This is the place where Lords Neuberger and Mance offered their reasoning on the matter by reference to:

Article 9 of the Bill of Rights, one of the pillars of constitutional settlement which established the rule of law in England in the 17th century, precludes the impeaching or questioning in any court of debates or proceedings in Parliament. Article 9 was described by Lord BrowneWilkinson in the House of Lords in Pepper v. Hart [1993] AC 593, 638, as "a provision of the highest constitutional importance" which "should not be narrowly construed."148

Thus, some constitutional principles may be more "constitutional" than others; further, could an EU directive be constructed which would require national courts to set aside the principle due to the superiority of EU law? For Lords Neuberger and Mance, the answer was that it probably would not. They seemed to misrepresent the House of Lord's instruction, relating to the treatment of national law, which contradicts EU law via the ECA 1972-that such legislation was to be held as "invalid," when really what the Lords held was that such laws could be disapplied by the courts. However, they proceeded by explaining how the ECA 1972 could not be interpreted as meaning that all legislation-especially those dealing with, for example, the rule of law-which were in conflict with EU law could be abrogated.

The analysis of the above cases is used to demonstrate that the basic notion of the supremacy of EU law over inconsistent national law derives its status from the ECA 1972. This was established, if were needed, in Factortame (No. 2) ${ }^{149}$-and through Thoburn, ${ }^{150}$ the court further offered direction that the ECA 1972 was a constitutional statute and thus immune from implied repeal. For future legislation to override the principles of the ECA 1972, it would have required specific and explicit repeal of those principles. More recently, in HS2, ${ }^{151}$ the Supreme Court explained how constitutional laws - be they legislative or established through the common law-are not equal and a hierarchy exists, thereby explaining a further nuance to laws which may be repealed and through which measures will be required. The ECA 1972 was deemed to have the status of being fundamentally constitutional in nature, and therefore Parliament did not intend for future legislation to abrogate the principles within it lightly. If we return to Thoburn, ${ }^{152}$ it is readily evident that the RTA88 would be defined as ordinary legislation and would not require discussion of the hierarchy between constitutional laws. Essentially, the ECA 1972 trumped the RTA88, and using this analysis - even more so in relation to administrative provisions contained within the UDA and UtDA - established as they were between a body designated as an emanation of the State and the Secretary of State. It would follow that it was available to national courts to disapply those national provisions which contradict directly effective elements of an EU directive-superior EU laws. Certainly, the contradicting aspects of the RTA88, UDA, and UtDA could not be read as overriding the judiciaries' obligation-flowing from Section 2 of the ECA 1972, "to be given legal effect or used in the United Kingdom."

\footnotetext{
${ }^{146} R$ (HS2 Action Alliance Ltd), 2014 UKSC 3.

${ }^{147}$ Thoburn, 2002 EWHC (Ch) 195.

${ }^{148} \mathrm{R}$ (HS2 Action Alliance Ltd), 2014 UKSC at para. 203.

${ }^{149}$ Factortame (No. 2), 19911 AC 603.

${ }^{150}$ Thoburn, 2002 EWHC (Ch) 195.

${ }^{151} R$ (HS2 Action Alliance Ltd), 2014 UKSC 3.

${ }^{152}$ Thoburn, 2002 EWHC (Ch) 195.
} 
Of course, the entire purpose of the discussion provided by Lords Neuberger and Mance is to further explain the very blunt constitutional tool which is Parliament's sovereignty-that enabled it to abrogate and derogate from EU law in as far as it chooses-albeit with the proviso that it makes such an intention sufficiently transparent and obvious. The judgment of the Lords tempers this approach through categorization of the ECA 1972 as being but one constitutional law which is potentially limited through the application of other constitutional laws-be they legislative or established through the common law. The status of the ECA 1972 did not credit it with a power to prevail over all other inconsistent Acts of Parliament, but it did offer the starting point for arguments regarding the hierarchy and status of laws, and whether implicit or explicit derogation was necessary to determine the primacy of EU law. This rejects the previously held view that the constitutional landscape - as provided for by Dicey—is flat and introduces a more uneven constitutional order, which will require calibration through judicial pronouncement.

\section{F. The Goal of Remedying UK Motor Vehicle Insurance Law: Interim Relief or Permanent Disapplication?}

There was no such power that could prevent the UK's national courts from granting interim relief or to permanently disapply the national motor insurance law-otherwise, such power would harm the effectiveness of EU law. ${ }^{153}$ The MSA88 was believed to be in breach of a fundamental EU principle - the free movement principle — where individuals and businesses used to rely on having the right to access to the UK fishing quota, as free movement shall not be restricted. Aspects of the motor insurance laws are in breach of the same EU fundamental principle-free movement. The applicants in Factortame, ${ }^{154}$ after an unsuccessful claim, ${ }^{155}$ sought judicial review in the UK-and to remove restriction on their rights of fishing in the UK water. ${ }^{156}$ The judicial review, however, failed to achieve anything of substance. As the judicial order - to restrain the government from the threat that the Act undermined EU law and to make restitution to the claimants-was refused, the case was referred to the Court of Justice through the House of Lords. ${ }^{157}$ Thereafter, the Court of Justice held that national laws of EU Member States should have no effect whatsoever beside EU law-national laws cannot prevent national courts from granting interim relief, where EU law is involved in a dispute. ${ }^{158}$ The Court of Justice held that the provisions of the MSA88 contravened EU law, and therefore were to be disapplied by UK national courts. ${ }^{159}$ In light of the Court of Justice judgment, the House of Lords granted an injunction in favor of the claimantFactortame. ${ }^{160}$ The motor insurance law has been challenged and many claims have proven unsuccessful. Some were referred to the Court of Justice and in some cases compensation was granted. However, it failed to remove the illegality of exclusion clauses and procedural rules. A judicial review also failed to bring the law into line with EU law. ${ }^{161}$ Therefore, if national courts failed to fulfill their duty and disapply the law, referral to the Court of Justice would need to be considered.

The MSA88 was disapplied by the UK national courts and the victims of the 1988 Act were duly compensated. Therefore, the authors argue that the directly effective aspects of the MVID-

\footnotetext{
${ }^{153}$ Schorsch Meier GmbH v. Hennin [1975] EWHC (QB) 416 (Eng.).

${ }^{154}$ Factortame (No. 2), 19911 AC 603.

${ }^{155}$ The claim came before the UK national law before its referral to the European Court.

${ }^{156} \mathrm{ECA}$ art. 43.

${ }^{157}$ The House of Lords was obliged-under Article 234 (ex 177), now Article 267 TFEU—to refer the case to the Court of Justice.

${ }^{158}$ Factortame (No. 2), 19911 AC 603.

${ }^{159} \mathrm{Id}$.

${ }^{160}$ The decision was made on October 11, 1990.

${ }^{161}$ RoadPeace, 2017 EWHC (Ch) 2725.
} 
Articles 3 and 10-required that the offending aspects of the RTA88, UDA, and UtDA should have been disapplied, and third-party victims of road traffic accidents-who suffered losses or injuries in the past and failed to secure fair compensation due to breaches of EU law-should have been compensated accordingly. For instance, in Factortame III, ${ }^{162}$ the Court of Justice held that the European Commission could take actions against any EU Member States that could be liable for damages, where it fails to comply with EU law. As explained earlier, the motor insurance law breached more than one fundamental EU principle; each of which is sufficient to have had the law disapplied-for example, the provisions and clauses in breach.

The power to disapply the RTA88, due to its infringement of the free movement of goods and persons, is compelling when compared with the infringement occurring in Factortame. ${ }^{163}$ It will be remembered in Factortame ${ }^{164}$ that the affected Spanish fishermen were not prevented, entirely, from access to British waters to undertake their professional activities; rather, the MSA88 applied conditions to be satisfied in order for such access to be effective. Therefore, had the fishermen domiciled themselves in the UK or registered their vessels in the UK, access would have been granted. Compare this with the current state of the RTA88. In its current reading and application, the Act did not prevent the free movement of people and goods from the EU to the UK. The RTA88 made the provision for the protection of third-party victims of motor vehicle accidents less beneficial than citizens would experience if the EU law had been correctly applied. However, on closer inspection, it may even be more compelling to have disapplied the offending provisions within the RTA88-when compared with the MSA88. As in Factortame, ${ }^{165}$ had the Spanish fishermen complied with the criteria identified in that Act, access-and therefore, the movement of goods and persons - could have been achieved. With respect to the RTA88, and to give just one example of Section 145 and the geographic scope of compulsory motor vehicle insurance-per $V n u k^{166}$ - it is actually not possible for an affected citizen to protect themselves against the actions of a negligent uninsured motorist for an accident occurring on private land. There are no comparable criteria within the RTA88 which, upon satisfaction, grant protection to the citizen. Citizens in the EU have the right to expect EU law to be applied in each Member State, and the MVID and the Court of Justice have clarified the issue regarding the geographic scope of compulsory motor vehicle insurance. That the RTA88 was not amended following the ruling in 2014, the judiciary was unwilling - even in recent cases - to understand or appreciate the significance and nuance within the reasoning of Vnuk, ${ }^{167}$ Andrade, ${ }^{168}$ and Juliana, ${ }^{169}$ and subsequently, citizens rightly lacked confidence in whether the law would be applied correctly and whether they would have access to the protection afforded at the EU level-this could have had tangible, negative effects on free movement. Personal insurance coverage would protect the individual against associated medical costs, but they would unlikely cover the suite of losses that would have been available against an insured and identified driver, and which should have been available through the MIB as insurer of last resort, in the event where no such coverage is available. Yet the national law failed in this duty, the courts frequently not applying EU law in any semblance of consistency with the provisions in the MVID, and the consequence was the exposure of risk to the individual third-party victim. Such a victim lacks the ability - which was even available to the Spanish fishermen-to facilitate free movement on terms comparable with citizens in other Member States.

\footnotetext{
${ }^{162}$ ECJ, Joined Cases 46 \& 48/93, Brasserie du Pêcheur v. Germany and R (Factortame) v. SS for Transport (No. 3), ECLI: EU:C:1996:79 (Mar. 5, 1996), http://curia.europa.eu/juris/liste.jsf?num=C-46/93.

${ }^{163}$ Factortame (No. 2), 19911 AC 603.

${ }^{164} I d$.

${ }^{165} I d$.

${ }^{166}$ Vnuk, Case C-162/13.

${ }^{167} \mathrm{Id}$.

${ }^{168}$ Andrade, Case C-514/16.

${ }^{169}$ Automóvel, Case C-80/17.
} 
HS2 extended the principle of disapplying an Act of Parliament in Factortame, ${ }^{170}$ based on a Treaty Article, and its reach now extends to the disapplication on the basis of an EU directive. Therefore, even if the view was that motor vehicle insurance law was not a direct aspect of the free movement principles of the EU—which, in any respect, we believe they are-and a treaty article, the MVID, as a Directive, was not in any meaningful way-hierarchical as opposed to its content - to the EIA Directive. They both imposed obligations on Member States to achieve the aims within, and indeed-given that aspects of the MVID had been held to have direct effect-it could be even argued that it had a greater argument for requiring offending national law to be disapplied than the EIA. ${ }^{171}$

In HS2, ${ }^{172}$ Lord Neuberger and Lord Mance refer to the source of the EIA for the subsequent adoption of the UK legislation. As the MVID began its life in 1972, albeit inspired by the UK RTA 1930, it has-through iterations in 1983, 1990, 2000, 2005, and 2009-initially been the precursor for aspects of the RTA88, and much more comprehensively the UDA-in 1988, 1999, and 2015 - and the UtDA-1996, 2003, and 2017. Thus, those provisions therein must have been viewed "as subject to a pre-condition that the legislative process must have enabled the objectives pursued by the Directive to be achieved." ${ }^{773}$ Further, Lord Neuberger and Lord Mance confirm that:

Under the European Communities Act 1972, United Kingdom courts have also acknowledged that European law requires them to treat domestic statutes, whether passed before or after the 1972 Act, as invalid if and to the extent that they cannot be interpreted consistently with European law. ${ }^{174}$

\section{G. Concluding Remarks}

Compulsory motor insurance law is of great importance for the functioning of the community and, consequently, on individuals' movements as drivers, passengers, and victims. The protection within the community must not be affected by or based on, for instance, where an accident takes place as far as it happened on community land. In other words, victims shall not be disadvantaged as to their claim, depending upon in which State the accident occurred; rather, they should be treated equally-in terms of the levels of compensation provided and the procedural rules applicable in national courts. ${ }^{175}$ Directives were chosen as the legislative method to achieve such goals, and they create the legal framework to guarantee that compensation is always available for victims of motor vehicle accidents by facilitating a claim directly against the responsible driver, their insurer-if applicable-or where impossible, from the relevant compensatory body. The MVID ensures that Member States have very little margins of discretion when it comes to derogating from these responsibilities - for example, through the operation of contractual exclusion clauses. Nevertheless, and as far as the UK is concerned, the government and the judiciary-interpreted broadly-seem to reject the notion that the MVID could have a broad interpretation, which meant that the UK failed to fulfill its duty to implement the MVIDs effectively. However, some of the blame for this state of affairs may be leveled at the EU itself, as the Commission failed to take any action in this respect to challenge UK national law. See, for instance, Lord Clyde's argument in Clarke v. Kato. ${ }^{176}$ Yet, given the political dimension to the

\footnotetext{
${ }^{170}$ Factortame (No. 2), 19911 AC 603.

${ }^{171}$ Council Directive 2009/31 (the Environmental Impact Assessment Directive), 2009 O.J. (L 140) 114 (EC).

${ }^{172} \mathrm{R}$ (HS2 Action Alliance Ltd), 2014 UKSC at 64.

${ }^{173} I d$.

${ }^{174} \mathrm{Id}$. at 72 .

${ }^{175}$ Bernáldez, Case C-129/94.

${ }^{176}$ Clarke v. Kato [1998] 233 N.R. 381 (HL) (appeal taken from Eng.).
} 
decisions of the Commission to seek infringement claims against Member States, ${ }^{177}$ and its complete discretion in this function, ${ }^{178}$ it is possible to excuse its lack of action in this regard.

This Article has identified those aspects of UK motor vehicle insurance law which contravened the MVID and undermined the free movement principles of the EU. Also, through Factortame (No. 2), ${ }^{179}$ it was constitutionally permissible for the courts to disapply an Act of Parliament that breached a fundamental aspect of EU law. Thoburn ${ }^{180}$ provides that "ordinary" Acts of Parliament cannot implicitly repeal a "constitutional" Act, and thus, the ECA 1972 could not be deemed to have been altered by the later RTA88. In HS2, ${ }^{181}$ the dicta of the Supreme Court identified a hierarchy between national constitutional Acts-which is not as relevant for the argument we present here, but is an interesting area for development, perhaps in a post-Brexit UK, with future trade deals and the basis on which they are concluded-but also that an EU directive had the power, at least in theory, to require change-and possibly disapplication-of a UK national Act of Parliament.

UK national law has led to a lesser level of protection for the victims of motor vehicle accidents than was required under EU law. It had created uncertainty for all parties, as to their legal rights and obligations. Given the problems with meaningful action by the State to rectify the law-see, for example, $V n u k^{182}$ - and the lack of instruction in the statutory and extra-statutory laws relating to the compulsory motor vehicle insurance on private land-the most compelling way to have provided this certainty and to ensure the fulfilment of the UK's obligations under EU law was for those offending aspects of the RTA88, UDA, and UtDA to have been disapplied. This course of action was not taken, and one may only ponder the benefits for third-party victims, the prominence that would have been given to EU law and the effects on constitutional law generally, if it had.

\footnotetext{
${ }^{177}$ See, e.g., Tanja A. Börzel, Non-compliance in the European Union: Pathology or Statistical Artefact?, 8 J. EUR. PUB. POLICY 803, 803-24 (2001).

${ }^{178}$ For commentary, see H.A.H. Audretsch, SUPERVision In EUROPEAN COMMUNity LAW (1986).

${ }^{179}$ Factortame (No. 2), 19911 AC 603.

${ }^{180}$ Thoburn, 2002 EWHC (Ch) 195.

${ }^{181} R$ (HS2 Action Alliance Ltd), 2014 UKSC 3.

${ }^{182}$ Vnuk, Case C-162/13.
}

Cite this article: Marson J, Alissa H, and Ferris K (2021). Resolving the Inconsistency Between National and EU Motor Insurance Law. Was Factortame the Solution Nobody Sought?. German Law Journal 22, 122-146. https://doi.org/10.1017/ glj.2020.98 